\title{
Studies of energy use by electric buses in SORT tests
}

In article the market for electric buses in the world and in Poland have been discussed. The test methods for energy consumption of citi buses in Poland and the appropriate measuring devices have been presented. The article presents the results of the energy consumption of the citi bus in the test SORT 2. The results obtained were referred to results in the case other electric and conventional buses.

Key words: electric, diesel, CNG, buses, SORT tests

\section{Introduction}

According to ACEA [2] the worldwide fleet of electrical vehicles (BEV and PHEV) in 2016 exceeded 2 million cars, of which 575 thousand in the US, 650 thousand in China, 157 thousand in Japan, 597 thousand in Europe and 84 thousand in remaining regions in the world. The sales of electrical cars increased from 548 thousand in 2015 to 775 thousand in 2016 (in the US from 115 to 159 thousand, in China from 208 to 352 thousand, in Europe from 188 thousand to 209 thousand, and in Japan it fell slightly from 25 thousand to 23 thousand).

According to UITP [1] buses perform $83 \%$ of public transport in the world (450 billion trips). A statistic bus passenger uses $1 / 3$ of fuel required for a passenger car. At present in Europe there are over 500 buses used with electric drive, of which $90 \%$ account for fully-electrical buses. The greatest number of those buses is used in the UK (130), Poland (78), the Netherlands (57), Germany (45), Sweden (39), France (31) and Spain (26). It should be borne in mind that the exhaust emission of $\mathrm{CO}_{2}$ from electrical buses depends on the source of electrical energy and for a standard bus is equal to 17 $\mathrm{gCO}_{2} \mathrm{e} / \mathrm{kWh}$ in case of wind energy, $122 \mathrm{gCO}_{2} \mathrm{e} / \mathrm{kWh}$ in case of Swiss energy mix and $579 \mathrm{gCO}_{2} \mathrm{e} / \mathrm{kWh}$ in case of German energy mix and $1005 \mathrm{gCO}_{2} \mathrm{e} / \mathrm{kWh}$ for the Polish energy mix.

The study of energy consumption by city buses is performed in the country - among others - in SORT track tests.

\section{SORT Standardised on-road test cycles}

The SORT project arose as an initiative of the UITP Bus Committee. The main aim of the SORT project is to design reproducible test cycles for on-road tests of buses in order to measure their fuel consumption [5].

Comparing the SORT cycles with this data shows a good match with reality. SORT 1 (heavy urban) with a standstill time of $40 \%$ and roughly 6 stops per kilometre fits very well for typical inner-city traffic situations (e.g. central Paris, France or London, UK). SORT 2 (easy urban) with $35 \%$ standstill time and roughly 3 stops per kilometre is closer to the situation of certain routes in Madrid, Spain or Munich, Germany. And last, SORT 3 (easy suburban) is representative of traffic in smaller cities (e.g. Klagenfurt, Austria or the suburban areas of Paris, France) - Figs 1-3.
The SORT 1 cycle, which is only $520 \mathrm{~m}$, must be run trough at least twice in succession $(=1040 \mathrm{~m})$. The SORT 2 $(920 \mathrm{~m})$ and SORT $3(1,450 \mathrm{~m})$ cycles need to be run trough, at least once.

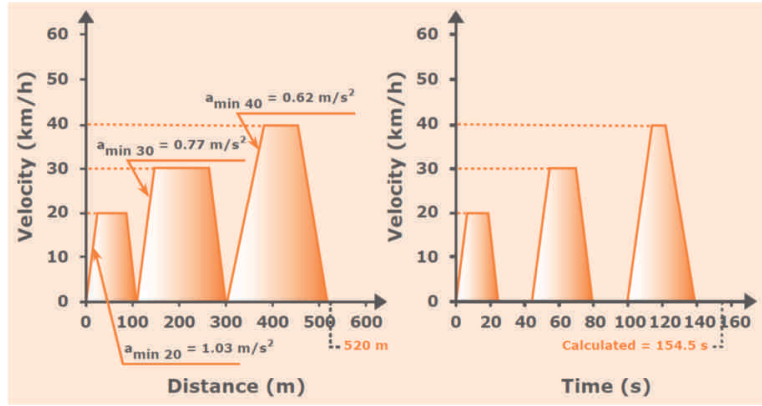

Fig. 1. SORT $1[5]$

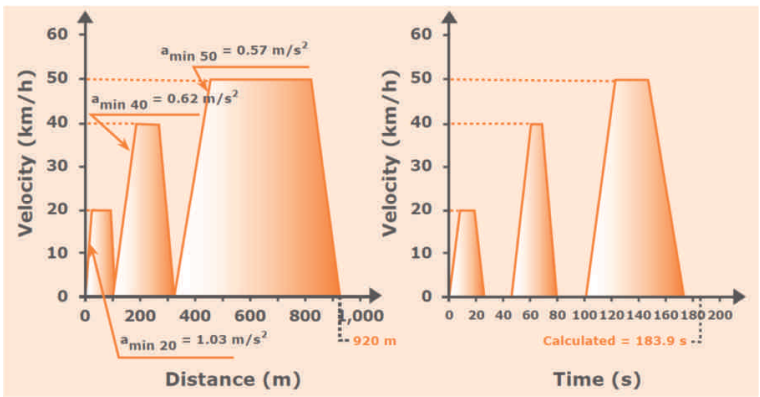

Fig. 2. SORT 2 [5]

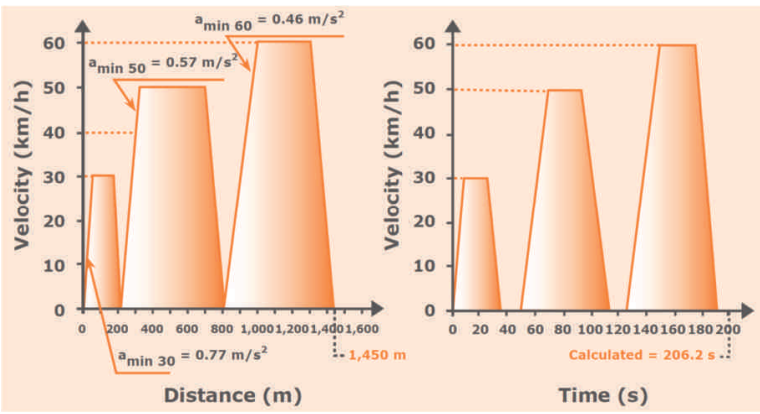

Fig. 3. SORT $3[5]$

The consumption measurements for each respective are to be repeated until 3 measurement lie within an accuracy 
requirement $2 \%$. To calculate the accuracy, the difference between the maximum and minimum consumption values of the three measurements is divided by the minimum value $\left(\left(\mathrm{C}_{\max }-\mathrm{C}_{\min }\right) / \mathrm{C}_{\min } \mathrm{x} 100\right)$.

The tolerance for trapezoidal target speed is $\pm 1 \mathrm{~km} / \mathrm{h}$. During the transition from acceleration phase to the phase of driving at a constant speed, a maximum deviation of +3 $\mathrm{km} / \mathrm{h}$ is permitted for a brief period. No more than 10 minutes should elapse between each measurement [6]. The above requirements were respected.

Wind speed was below $3 \mathrm{~m} / \mathrm{s}$, external temperature was range between $0^{\circ} \mathrm{C}$ and $30^{\circ} \mathrm{C}$, humanidity level was below $95 \%$ in all conducted tests. Other requirements of SORT procedure were also met as required.

\section{Tested vehicles}

The tested vehicles consisted of 12-metre city buses:

- a bus marked as A1 with SI engine, fuelled with CNG with nominal power of $222 \mathrm{~kW}$;

- a bus marked as A2 with a SI engine fuelled with diesel fuel, with nominal power $209 \mathrm{~kW}$.

- a bus marked as A3, the so-called BEV, powered/driven by two electrical engines with nominal power of $2 \times 182$ $\mathrm{kW}$ (limited to $2 \times 110 \mathrm{~kW}$ ).

The mass of buses A1, A2 and A3 was equal to respectively $12,260 \mathrm{~kg}, 10,600 \mathrm{~kg}, 11,300 \mathrm{~kg}$.

\section{Test equipment}

The tests of buses were performed with the use of the following testing equipment: KMA Mobile Fuel Flow Meter to measure the consumption of diesel fuel, CMF $025 \mathrm{M}$ Mass Flow Meter From Emerson to measure the consumption of CNG, Yokogawa WT 1800E Power Analyzer to measure the consumption of electrical energy and Datron mEEP20 used - among others - to measure the velocity and displacement of buses.

The universal system for fuel consumption measurement - AVL KMA Mobile is used to measure the fuel consumption in vehicles and on the engine test benches.

Basic parameters:

- measuring range: $0.35-150 \mathrm{dm}^{3} / \mathrm{h}$

$0.26-110 \mathrm{~kg} / \mathrm{h}$ (with the fuel density: $0.75 \mathrm{~g} / \mathrm{cm}^{3}$ )

- density meter: $500-2000 \mathrm{~kg} / \mathrm{m}^{3}$

- density measurement uncertainty: $1 \mathrm{~kg} / \mathrm{m}^{3}$

- measurement uncertainty (repeatability of the sensor calibration coefficients): $\pm 1 \%$ (readout)

- measurement media (measuring module): petrol, fuels of standard and super quality (leader petrol/unleaded) also with alcohol admixtures; methanol, ethanol etc. to 100\%; diesel oil; biodiesel.

Fig. 4 presents KMA Mobile Fuel Flow Meter used in tests.

Mass flow meter for gas fuel consumption measurement is shown in the Fig. 5. Used to measure a mass of gas consumption in vehicles and on the engine test bench. It also allows for measuring gas density. The software used allows for recording the momentary values of the parameters measured.

Basic parameters:

- maximum mass flow intensity: $2180 \mathrm{~kg} / \mathrm{h}$

- accuracy of mass flow intensity measurement: $\pm 0.35 \%$
- repeatability of mass flow intensity measurement: $\pm 0.20 \%$

- measurement media: gas fuels, also in liquid form (for example LNG).

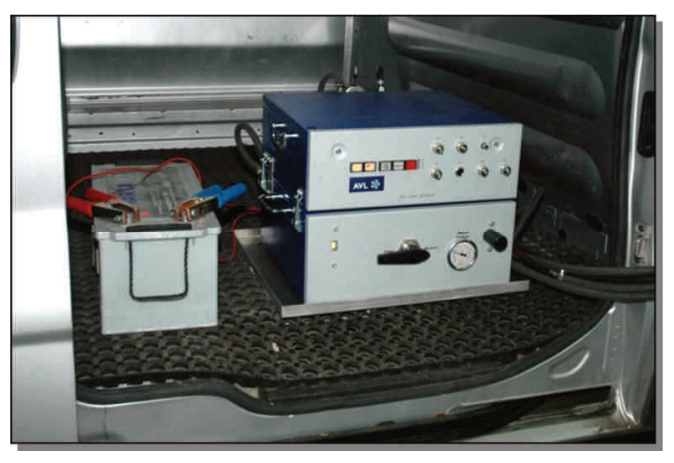

Fig. 4. KMA Mobile Fuel Flow Meter

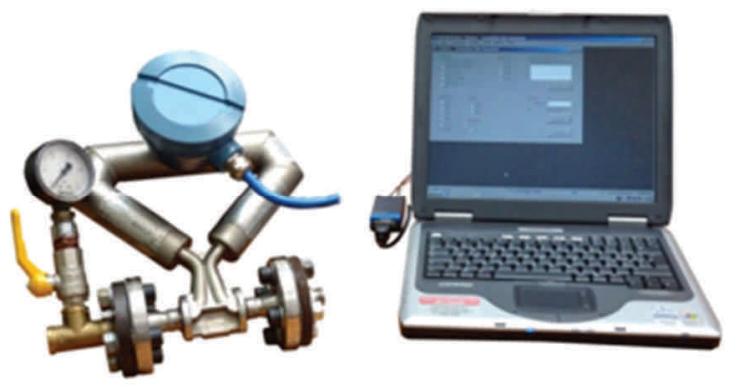

Fig. 5. CMF 025M Mass Flow Meter From Emerson

Fig. 6 shows Yokogawa WT 1800E Power Analyzer.

The WT $1800 \mathrm{E}$ is a versatile instrument, unlocking precision power measurement capabilities for researches, designers and engineers working on a wide variety of applications in energy efficiency and conservation and renewable energy. Key applications include: Electric, Hybrid Electric and Plug-in Hybrid Electric. The WT 1800E guarantees a power accuracy of $0.05 \%$ of reading plus $0.05 \%$ of range and is capable of harmonics analysis up to the $500^{\text {th }}$ order of a $50 / 60 \mathrm{~Hz}$ fundamental frequency. The stability of the WT $1800 \mathrm{E}$ ensures that precision measurements can be made today and over the long term.

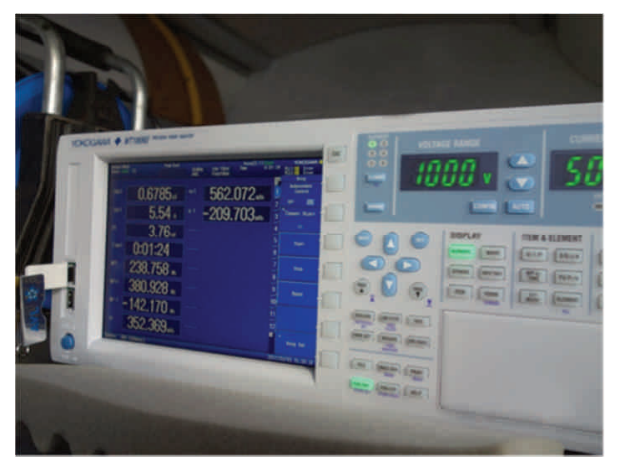

Fig. 6. Yokogawa WT 1800E Power Analyzer

Figure 7 presents Datron mEEP20 recorder with optical head allows the registration of the vehicle traffic conditions on the road. 
Multi-channel recorder allows simultaneous recording of multiple analogue signals such as weight, digital and frequency signals. Basic parameters:

- speed measuring range: $0.5-400 \mathrm{~km} / \mathrm{h}$

- repeatability: $\pm 0.5 \%$

- linearity of speed and road measurement: $\pm 0.25 \%$

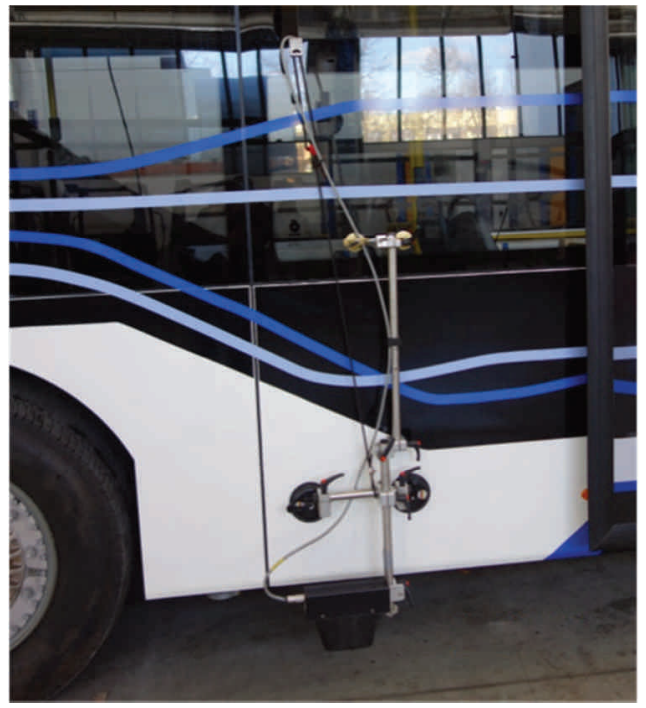

Fig. 7. Datron mEEP20

\section{Results and analysis of tests}

During the tests of consumption of fuel and electrical energy for all three buses all requirements of SORT procedure have been fulfilled with regard to ambience conditions (temperature, pressure and air humidity, wind speed), testing track or method of replicating the tracking cycle. One of the exceptions was the different method of determining additional load for a bus with an electrical drive.

The weight of additional load to be used for the tested bus was calculated for buses fuelled with diesel and CNG according to the requirements of SORT procedure.

The said procedure assumes that measurements are carried out with half of the bus load capacity and the weight is assumed equal to $3200 \mathrm{~kg}$, adjusted because of the bus size and number of seats or fuel tank capacity.

Thus, the calculated weight of the load does not correspond precisely with half of the actual load capacity of the tested bus. In case of tests of buses with electrical drive, the weight of additional load was calculated based on half of the product of the total number of passengers and weight per passenger equal to $68 \mathrm{~kg}$. The difference in the adopted method of determining the weight of additional load was due to the fact that the SORT procedure has not been yet established for buses with electrical drive. If the method were to be applied to determine the weight of additional load in the current version of SORT procedure, the weight of the bus could be inflated or understated during the tests as one of the elements taken into consideration in the calculations is the fuel tank capacity.

According to SORT procedure the fuel tank capacity of a model bus is $200 \mathrm{dm}^{3}$, i.e. the weight of diesel fuel in such bus amounts to $168 \mathrm{~kg}$. Depending on whether the tank of the tested bus has a smaller or bigger capacity, the weight of additional load is adjusted by taking away or adding the weight resulting from the difference between the mass of fuel in the tested bus and $169 \mathrm{~kg}$. In case of buses with electrical drive there is no container for liquid fuel. Such tanks are traditional batteries, the weight of which is considerably greater than the weight of diesel fuel in the bus, and depending of their capacity it can differ significantly, influencing the weight of the bus and total number of passengers.

For example, the weight of traditional batteries in the tested electrical bus ranged from 1920 to $2520 \mathrm{~kg}$, the weight of the bus - from $11,709 \mathrm{~kg}$ to $12,309 \mathrm{~kg}$ and the total number of passengers from 83 to 76 .

The tests were performed in accordance with SORT 2 procedure.

Figure 8 presents a good performance of SORT 2 test as regards its replication in case of one of the tested buses. The bus drives - whenever possible - at velocities of trapeses - as marked on the graph - in general without or just slightly exceeding the maximum speed in each trapeze. A similarly good performance of SORT 2 test occurred in case of the remaining tested buses.

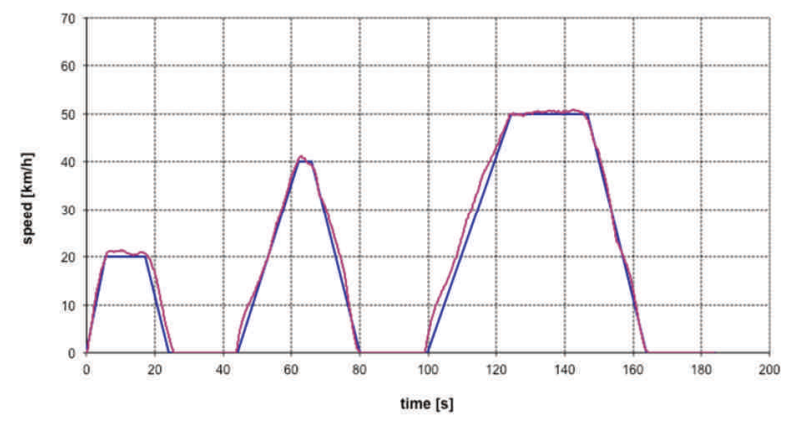

Fig. 8. SORT 2 chart (bus A2)

Table 1 presents the results as regards the consumption of fuel and electrical energy per route in SORT 2 cycle for the tested 12-metre buses.

Table 1. Results of consumption of fuel and electrical energy per route in SORT 2 cycle for tested 12-metre buses

\begin{tabular}{|l|c|c|c|}
\hline $\begin{array}{c}\text { Specifica- } \\
\text { tion of } \\
\text { buses }\end{array}$ & Fuel/ drive & $\begin{array}{c}\text { Fuel consump- } \\
\text { tion/Electric } \\
\text { energy consump- } \\
\text { tion per } 100 \mathrm{~km}\end{array}$ & $\begin{array}{c}\text { Fuel consump- } \\
\text { tion/Electric } \\
\text { energy consump- } \\
\text { tion per } 1 \mathrm{~km}\end{array}$ \\
\hline A1 & CNG & $49.2 \mathrm{Nm}^{3} / 100 \mathrm{~km}$ & $4.98 \mathrm{kWh} / \mathrm{km}$ \\
\hline A2 & Diesel fuel & $39.4 \mathrm{dm}^{3} / 100 \mathrm{~km}$ & $3.90 \mathrm{kWh} / \mathrm{km}$ \\
\hline A3 & Electric & $94.9 \mathrm{kWh} / 100 \mathrm{~km}$ & $0.95 \mathrm{kWh} / \mathrm{km}$ \\
\hline
\end{tabular}

According to Table 1 the consumption of energy per route $(\mathrm{kWh} / \mathrm{km})$ in case of a bus with an engine fuelled with CNG is almost 5 times greater and in case of diesel-fuelled bus is almost 4 times greater than the consumption of energy per route of an electrical bus.

The first experience in annual use of electrical buses in Warsaw by Miejskie Zakłady Autobusowe in the capital city (10 buses along the highly loaded urban line 222 (heavy-duty line SORT 1), with water heating system and an additional combustion aggregate fuelled with diesel) show that while average consumption of electrical energy per route comes to $103 \mathrm{kWh} / 100 \mathrm{~km}$, the consumption of electrical energy per air-conditioning accounts for approx. 
$25 \%$ per route $(25 \mathrm{kWh} / 100 \mathrm{~km})$, and the use of electrical energy for the heating system accounts for c.a. $150 \%$ of energy consumption per route, i.e. approx. $170 \mathrm{kWh} / 100$ $\mathrm{km}$ (SORT 1, $24 \mathrm{~h}$ temperature from -10 to $-15^{\circ} \mathrm{C}$ ) [3, 4].

Moreover, the use of an electrical heating system may in low temperatures of the ambience - reduce the range of the bus three times and the total energy consumption at -10 to $-15^{\circ} \mathrm{C}$ comes to approx. $300 \mathrm{kWh} / 100 \mathrm{~km} \mathrm{[4].}$

In such case the aforesaid differences in the consumption of energy in the tested buses fuelled with $\mathrm{CNG}$ or diesel are not considerably greater compared to the consumption of energy by an electrical bus. Nevertheless, electrical energy consumption by an electrical bus is still the lowest.

At the same time, attention must be given to the fact that in the light of data presented in [4] the technical readiness ratio for electrical buses compared to conventional bus fuelled with diesel is lower (on average for example in the period from July 2015 to April 2016 - respectively 0.883 and 0.981).

Based on prices of fuels and electrical energy the cost per $1 \mathrm{~km}$ was compared for the tested buses in terms of fuel/energy consumption. The price of diesel fuel and electrical energy was provided by one of the major domestic carriers, the price of CNG was calculated according to an average price quoted by PGNiG within the period from May 2015 to April 2016. The results of the comparison are shown in Table 2.
Table 2. Comparison of costs per $1 \mathrm{~km}$ in tested buses in terms of fuel/energy consumption

\begin{tabular}{|c|c|c|c|}
\hline Bus & Fuel/drive & $\begin{array}{c}\text { Net price of fuel/electrical } \\
\text { energy }\end{array}$ & Cost of $1 \mathrm{~km}$ \\
\hline A1 & CNG & $2.58 \mathrm{zl} / \mathrm{m}^{3}$ & $1.27 \mathrm{zl} / \mathrm{km}$ \\
\hline A2 & ON & $3.33 \mathrm{zl} / \mathrm{dm}^{3}$ & $1.31 \mathrm{zl} / \mathrm{km}$ \\
\hline A3 & electrical & $0.36 \mathrm{zl} / \mathrm{kWh}$ & $0.34 \mathrm{zl} / \mathrm{km}$ \\
\hline
\end{tabular}

Prices of fuel/electrical energy do not include value added taxon respective fuels.

\section{Summary}

The resulting values of consumption of diesel fuel are confirmed in actual use. According to MZA [3] on the routes corresponding to traffic conditions defined in SORT 2 the average consumption of diesel fuel of a 12-metre bus is equal to $39 \mathrm{dm}^{3} / 100 \mathrm{~km}$ [3]. However, for buses with electrical drive the consumption of electrical energy may differ considerably compared to the intended value due to the use of additional devices consuming power or ambient temperature.

Nevertheless, the tests prove that electrical buses characterise with lower energy consumption than buses with conventional engines powered with CNG or diesel fuel.

Lower are also costs per $1 \mathrm{~km}$ by electrical buses which result only from the consumption of fuel/electrical energy.

\section{Nomenclature}

ACEA European Automobile Manufacturers Association

BEV battery electric vehicle

CNG compressed natural gas

ON diesel fuel

PGNiG Polish Oil and Gas Company

PHEV plug-in hybrid electric vehicle

SI spark ignition

SORT standardised on-road test

UITP Association of Public Transport

\section{Bibliography}

[1] BRUGE, P. UITP Vision. 5th European Battery. Hybrid and Fuel Cell Electric vehicle Congress (EEVC-2017). Geneva, 14-16 March 2017.

[2] DOLEJSI, P. ACEA perspective on alternatively powered vehicles. 5th European Battery. Hybrid and Fuel Cell Electric vehicle Congress (EEVC-2017). Geneva, 14-16 March 2017.

[3] KUŹMIŃSKI, J. Koszty eksploatacji autobusów elektrycznych. MZA Sp. z o.o. Konferencja E-bus. "Praktyczne

\author{
Wojciech Gis, DSc., DEng. - Motor Transport \\ Institute. \\ e-mail: Wojciech.Gis@its.waw.pl
}

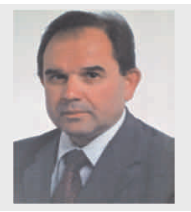

Andrzej Wierzejski, MEng. - Motor Transport Institute.

e-mail: Andrzej.Wierzejski@its.waw.pl aspekty elektryfikacji transport publicznego". Ministerstwo Rozwoju, 30.03.2017, Warszawa.

[4] KUŹMIŃSKI, J., GOGACZ, R., BARTOSIŃSKI, T. Doświadczenia w rocznej eksploatacji autobusów elektrycznych w Warszawie. Autobusy. Technika, Eksploatacja, Systemy Transportowe. 2016, 7-8.

[5] Projekt UITP „SORT”. Znormalizowane cykle testów jezdnych. UITP, 2013.

[6] UITP PROJECT 'SORT'. Standardised On-Road Test Cycles. International Association of Public Transport, 2014.

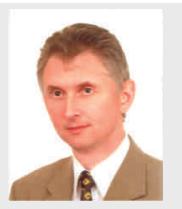

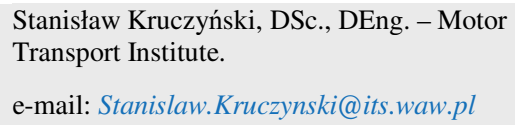

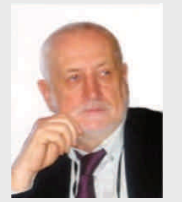

Sławomir Taubert, MEng. - Motor Transport Institute.

e-mail: Slawomir.Taubert@its.waw.pl 